\title{
PENINGKATAN KAPASITAS KELUARGA DALAM PERAWATAN AKTIFITAS SEHARI-HARI PASIEN GAGAL JANTUNG.
}

\author{
Sulastini ${ }^{1}$, Devi Ratnasari ${ }^{2}$, Andri Nugraha ${ }^{3}$, Hasbi Taobah Ramdani ${ }^{4}$, \\ Bambang Aditya Nugraha ${ }^{5}$ \\ 1,2,3,4 Program Studi S1 Keperawatan STIKes Karsa Husada Garut \\ ${ }^{5}$ Program Studi S1 Keperawatan Universitas Padjadjaran Bandung \\ Jln. Nusa Indah no. 24 Garut Jawa Barat \\ email :sulastini26@gmail.com
}

\begin{abstract}
ABSTRAK
Gagal jantung di Indonesia menjadi masalah yang menyebabkan banyaknya angka kesakitan maupun kematian. Pasien dengan gagal jantung umumnya mengalami penurunan kapasitas fungsional dan sesak napas (dipsnea) ketika beraktivitas maupun ketika istirahat. Pola aktifitas pada pasien dengan gagal jatung sangat terbatas, pola aktifitas akan berubah terutama pada saat pasien mengalami sesak nafas yang cukup berat. Kondisi inilah yang menyebabkan pasien gagal jantung mengalami penurunan dalam menjalankan aktivitas sehari-hari. Proses penyembuhan pada pasien gagal jantung harus dilakukan secara holistik dan melibatkan anggota keluarga. Tujuan program pengabdian masyarakat ini adalah meningkatkan kapasitas dukungan keluarga dalam perawatan aktifitas sehari-hari pasien gagal jantung dalam masa rehabilitative. Metode yang digunakan dalam kegiatan ini adalah penyuluhan kesehatan langsung kepada anggota keluarga pasien gagl jantung. Hasil dari program penykuhan ini adalah membantu keluarga memiliki informasi yang memadai tentang pentingnya dukungan keluarga dalam proses perawatan aktifitas seharihari pasien gagal jantung sehingga akan membantu proses pemulihan serta peningkatan kualitas hidup.
\end{abstract}

\section{Kata Kunci : Dukungan keluarga, Aktifitas sehari-hari, Gagal Jantung}

\begin{abstract}
Heart failure in Indonesia is a problem that causes many morbidity and mortality. Patients with heart failure generally experience decreased functional capacity and shortness of breath (dipsnea) when on the move or at rest. The pattern of activity in patients with heart failure is very limited, the pattern of activity will change especially when the patient experiences severe shortness of breath. This condition causes heart failure patients to experience a decrease in carrying out daily activities. The healing process in patients with heart failure must be done holistically and involve family members. The purpose of this community service program is to increase the capacity of family support in caring for the daily activities of heart failure patients during the rehabilitative period. The method used in this activity is direct health education to family members of heart failure patients. The results of this outreach program are to help families have adequate information about the importance of family support in the process of caring for the daily activities of heart failure patients so that it will help the recovery process and improve the quality of life.
\end{abstract}

\section{Keywords : Family Support, Daily Activities, Heart Failure}




\section{PENDAHULUAN}

$\begin{array}{crr}\text { Gagal } & \text { Jantung } & \text { adalah } \\ \text { ketidakmampuan } & \text { jantung } & \text { untuk }\end{array}$ memompa darah yang adekuat untuk memenuhi kebutuhan jaringan akan oksigen dan nutrisi (Smeltzer, Bare, Hinkle, \& Cheever, 2010). Menurut data World Health Organization (WHO) (2013) 17,3 juta orang meninggal akibat gangguan kardiovaskular pada tahun 2008 dan lebih dari 23 juta orang akan meninggal setiap tahun dengan gangguan kardiovaskular. Data dan Riset Kesehatan Dasar tahun 2007 menyebutkan bahwa penyakit jantung masih merupakan penyebab utama dari kematian terbanyak pasien di rumah sakit Indonesia.

Gagal jantung di Indonesia menjadi masalah yang menyebabkan banyaknya angka kesakitan maupun kematian. Menurut data Riset Kesehatan Dasar Nasional (RISKESDAS) tahun 2013 menunjukkan bahwa prevalensi penyakit gagal jantung meningkat seiring bertambahnya umur. Penderita tertinggi pada umur 65-74 tahun sebesar $0,5 \%$. Pada umur $\geq 75$ tahun mengalami penurunan yaitu $0,4 \%$. Bagi yang terdiagnosis dokter atau mempunyai gejala tertinggi terjadi pada umur $\geq 75$ tahun yaitu sebesar $1,1 \%$. Jumlah yang berhasil terdiagnosis oleh dokter, prevalensinya lebih tinggi pada perempuan sebesar $0,2 \%$ dibandingkan dengan laki-laki yaitu $0,1 \%$. Sehingga prevalensi penyakit gagal jantung di Indonesia sebesar 0,3\% (RISKESDAS, 2013).

Pada tahun 2014 angka kesakitan gagal jantung di Kabupaten Garut berjumlah 1.460 pasien sedangkan jumlah pasien rawat inap gagal jantung periode Januari 2015 sampai dengan Februari 2016 berjumlah 1.680. Hal ini menunjukan bahwa prevalensi gagal jantung di kabupaten garut mengalami peningkatan sebanyak 220 kasus sejak tahun 2014.
Manifestasi klinis yang muncul pada pasien dengan gagal jantung adalah dyspnea, takikardi, kelelahan, intoleransi aktifitas, retensi cairan, penurunan kadar oksigen darah arteri, edema paru, edema perifer, ketidaknyamanan, dan gangguan pola aktifitas (Yancy et al., 2013). Pola aktifitas pada pasien dengan gagal jatung sangat terbatas, pola aktifitas akan berubah terutama pada saat pasien mengalami sesak nafas yang cukup berat. Intoleransi aktivitas pada penderita gagal jantung satu dengan yang lain dapat berbeda tergantung dari kapasitas fungsional. Kapasitas fungsional merupakan kemampuan seseorang dalam melakukan aktivitas yang biasa dilakukan dalam kehidupan sehari-hari (Wenger, 1989 dalam Suharsono, 2011). Pasien gagal jantung yang mengalami kelainan struktur dan fungsi jantung menyebabkan kerusakan fungsi ventrikel untuk memenuhi kebutuhan nutrisi dan oksigen ke jaringan tubuh. Kondisi ini menyebabkan pasien dengan gagal jantung umumnya mengalami penurunan kapasitas fungsional dan sesak napas (dipsnea) ketika beraktivitas maupun ketika istirahat. Kondisi inilah yang menyebabkan pasien gagal jantung mengalami penurunan dalam menjalankan aktivitas sehari-hari.

Proses penyembuhan pada pasien gagal jantung harus dilakukan secara holistik dan melibatkan anggota keluarga. Dukungan keluarga sangatlah penting bagi pasien dengan gagal jantung, selain membantu dalam hal pola aktivitas sehari-hari dan terapi dukungan keluarga juga sangat diperlukan dalam hal psikologis sehingga diharapkan dapat meningkatkan kualitas hidup pasien (Shahriari, et al, 2013). Adanya perhatian, kasih sayang, nasehat, dan bantuan yang diberikan anggota 
keluarga pada pasien gagal jantung akan memberikan rasa tenang dan aman yang dapat membantu pemulihan gagal jantung (Ades, 2010). Berdasarkan hal di atas, kami mengadakan kegiatan pengabdian masyarakat pada anggota keluarga pasien yang mengalami gagal jantung melalui pemberian pendidikan kesehatan terkait pentingnya dukungan keluarga dalam perawatan aktifitas sehari-hari pasien gagal jantung.

\section{METODE}

Kegiatan pengabdian masyarakat ini dilaksanakan di ruang tunggu Cardiac Centre RSU dr. Slamet Garut. Subjek dalam kegiatan ini adalah anggota keluarga pasien gagal jantung yang sedang di rawat di ruang Cardiac Centre RSU dr. Slamet Garut sebanyak 35 orang, metode yang diterapkan dalam kegiatan ini adalah sebagai berikut :

1. Penyuluhan dengan menggunakan slide dengan materi pola aktifitas pasien gagal jantung serta pentingnya dukungan keluarga dalam perawatan pola aktifitas sehari-hari pasien

2. Simulasi kegiatan sehari-hari pasien gagal jantung yang harus dibantu keluarga seperti mempersiapkan makanan, pergi ke toilet, melakukan kegiatan ibadah, serta mendekatkan barang-barang pribadi yang biasa digunakan dalam kegiatan seharihari

3. Tanya jawab metode ini digunakan untuk memberikan kesempatan kepada peserta untuk menanyakan hal-hal tertentu yang dianggap belum jelas serta untuk mengevaluasi pemahaman peserta terkait materi yang diberikan

\section{HASIL DAN PEMBAHASAN}

Rangkaian kegiatan pendidikan kesehatan yang telah dilakukan meliputi persiapan, pelaksanaan dan evaluasi kegiatan. Pada tahapan persiapan tim pengabdian masyarakat menyiapkan tempat, alat, satuan acara penyuluhan, materi, media penyuluhan, instrument, serta leaflet. Pada tahap pelaksanaan materi terkait dukungan keluarga dalam pola aktifitas sehari-hari pasien gagal jantung dipresentasikan oleh pemateri dalam waktu 45 menit. Pada tahap akhir yaitu evaluasi kegiatan tim memberikan evaluasi berupa pertanyaan lisan kepada peserta.

Tabel 1. Alat dan Bahan Pendidikan Kesehatan

\begin{tabular}{clc}
\hline No & \multicolumn{1}{c}{ Alat dan Bahan } & N \\
\hline 1 & LCD & 1 \\
2 & Laeflet & 35 \\
3 & Poster & 3 \\
4 & Microphone & 1 \\
5 & Kursi Panjang & 7 \\
\hline
\end{tabular}

\section{PEMBAHASAN}

Hasil dari program ini membantu meningkatkan pengetahuan dan kapasitas keluarga terkait pentingnya dukungan keluarga dalam perawatan aktifitas sehari-hari pada pasien gagal jantung. Pengetahuan adalah suatu hasil dari rasa keingintahuan melalui proses sensoris, terutama pada mata dan telinga terhadap objek tertentu. Pengetahuan merupakan domain yang penting dalam terbentuknya perilaku terbuka atau open behavior (Donsu, 2017).

Pola aktifitas pasien dengan gagal jantung sangat dibatasi. Pergerakan minimal untuk pasien dengan gangguan gagal jantung sangat dianjurkan. Pasien disarankan untuk bedrest sebagai terapi untuk mengurangi beban jantung seseorang. Dengan aktivitas yang berlebihan dapat mengakibatkan kerja jantung semakin meningkat sehingga beban jantung lebih berat (Shahriari et al., 2013). Oleh karena itu, pasien dengan gagal jantung lebih disarankan untuk mengurangi aktivitas yang berat. Pasien dengan gagal jantung masih dapat melakukan aktivitas namun disesuaikan dengan toleransi tubuh. Karena aktivitas 
diperlukan tubuh untuk melatih kapasitas fungsional jantung tetapi juga ditujukan supaya aktivitas tersebut tidak juga menjadi faktor pemberat terjadinya serangan jantung. Selama proses perawatan terhadap pasien dengan gangguan gagal jantung diperlukan aktivitas yang minimal atau tidak berlebihan untuk mengurangi beban kerja jantung.

Pasien gagal jantung perlu untuk diajarkan melakukan aktivitas secara bertahap dengan tujuan toleransi aktivitas dapat meningkat pula. Aktivitas dilakukan dengan melihat respon sepeti peningkatan nadi, sesak napas dan kelelahan. Aktivitas akan melatih kekuatan otot jantung sehingga gejala gagal jantung semakin minimal. Aktivitas ini akan dapat dilakukan secara informal dan lebih efektif apabila dirancang dalam program latihan fisik yang terstruktur (Nicholson, 2007).

Keluarga pasien perlu mempunyai sikap yang positif untuk membantu penyembuhan pada pasien khususnya pada pasien dengan penyakit jantung yang memerlukan pengobatan dan perawatan dalam jangka panjang. Keluarga perlu memberikan dukungan (support) kepada pasien untuk meningkatkan motivasi dan tanggung jawab untuk melaksanakan perawatan secara mandiri termasuk kegiatan sehari-hari pasien. Keluarga perlu mempunyai sikap menerima pasien, memberikan respon positif kepada pasien, menghargai pasien sebagai anggota keluarga dan menumbuhkan sikap tanggung jawab pada pasien (Komalasari, 2009). Adanya perhatian, kasih sayang, nasehat, dan bantuan yang diberikan anggota keluarga pada pasien gagal jantung akan memberikan rasa tenang dan aman yang dapat membantu pemulihan gagal jantung (Zulmi, 2018). Dukungan keluarga akan menjadi optimal dengan saling berkomunikasi dan menghormati serta menghargai pasien sebagai salah satu anggota keluarga, dengan dukungan keluarga yang optimal diharapkan kualitas hidup pasien dapat meningkat (Suharsono, 2011).

Keluarga sebagai orang terdekat pasien yang selalu siap memberikan dukungan moril maupun materi yang dapat berupa informasi, perhatian, bantuan nyata dan pujian bagi klien sehingga responden merasa terkurangi bebannya dalam menjalani perawatan. Hal ini sesuai dengan teori dari Choen dan Shime (2008) bahwa anggota keluarga menganggap bahwa orang yang bersifat mendukung selalu siap memberikan pertolongan dan bantuan jika diperlukan. Pasien dengan dukungan yang tinggi akan memberikan koping yang positif.

Menurut Commission on the Family (1998) dalam Setiadi (2008) bahwa dukungan keluarga dapat memperkuat setiap individu, menciptakan kekuatan keluarga, memperbesar penghargaan terhadap diri sendiri, mempunyai potensi sebagai strategi pencegahan yang utama bagi seluruh keluarga dalam menghadapi tantangan kehidupan sehari-hari serta mempunyai relevansi dalam masyarakat yang berada dalam lingkungan yang penuh dengan tekanan. Tanpa dukungan keluarga pasien akan sulit sembuh, mengalami perburukan dan sulit untuk bersosialisasi.

Dukungan keluarga sangat memainkan peran yang bersifat mendukung selama penyembuhan dan pemulihan anggota keluarga yang sakit. Menurut Safitri (2016) menyatakan bahwa dukungan keluarga merupakan salah satu faktor yang mempengaruhi ketidakpatuhan. Keluarga dapat membantu menghilangkan godaan pada ketidakpatuhan dan keluarga sering kali menjadi kelompok pendukung untuk kepatuhan pasien dalam menjalankan program terapi. 


\section{KESIMPULAN DAN SARAN}

Pendidikan kesehatan telah dilakukan untuk meningkatkan kapasitas keluarga dalam perawatan aktifitas sehari-hari pasien gagal jantung, sehingga akan membantu proses pemulihan serta peningkatan kualitas hidup pasien gagal jantung. Saran untuk program pengabdian masyarakat selanjutnya adalah pembuatan booklet tentang pengeloaan aktifitas sehari-hari yang bisa digunakan oleh pasien dan keluarga.

\section{UCAPAN TERIMA KASIH}

Ucapan terima kasih diberikan kepada pimpinan STIKes Karsa Husada Garut yang telah memberikan dana kegiatan pengabdian ini dan juga kepada pihak Rumah Sakit dr. Slamet Graut khususnya ruang Cardiac Centre.

\section{DAFTAR PUSTAKA}

Ades, P. A. (2010). "Cardiac rehabilitation and secondary prevention of coronary heart disease." The New England journal of medicine 345(12): 892.

Komalasari, Eti. (2009). Dukungan Sosial Pada Penderita Sakit Jantung Di Rumah Sakit Harapan Kita Jakarta. Skripsi-publikasi. Jakarta. Jurnal Gunadarma.

Black \& Hawks. (2009). Medical Surgical Nursing Clinical Management For Positive Outcomes. St. Louis. Missouri Elsevier Saunders

Cohen, S., Syme, S. L. (2008). Social Support And Health. Florida. Academic Press, Inc.

Friedman. 2012. Keperawatan Keluarga. Yogyakarta. Gosyen Publishing

Nicholson, C. (2007). Heart failure, A clinical nursing handbook. John Wiley \& Sons. Ltd.

Riset Kesehatan Dasar (Riskesdas). (2013). Badan Penelitian dan
Pengembangan

Kesehatan

Kementerian

RI tahun

2013.Diakses: 19 Maret 2017, dari

http://www.depkes.go.id/resources/

download/general/Hasil\%20Riskes

das\%202013.pdf

Safitri, Meutia, Cut. (2016). Hubungan dukungan keluarga dengan tingkat depresi pasien gagal jantung di poliklinik jantung RSUD. Dr. Zainoel Abidin. Etd.unsyiah.ac.id

Setiadi. (2008). Konsep \& keperawatan keluarga. Yogyakarta : Graha ilmu

Suharsono, T. (2011). Dampak home based exercise training terhadap kapasitas fungsional dan kualitas hidup pasien gagal jantung di RSUD Ngudi Waluyo Wlingi. Tesis FIKUI.

Shahriari, Mohsen. Ahmadi, Maryam. Babaee, Sima. Mehrabi, Tayebeh. Sadeghi, Masoumeh . (2013). Effects of a family support program on self-care behaviors in patients with congestive heart failure. Iran J Nurs Midwifery Res. 2013 MarApr; 18(2): 152-157.

World Health Organization. (2013). World health statistic. Di ambil dari http://search.who.int/search

Yancy,W,C., Jessup,Mariell., Chair,Vice., Bozkurt., Biykem., Butler, Javed., \& Casey, Donald, E. (2013). Conrad, A. Roth, TW. (2007). Muscle Relaxation Therapy for anxiety disorders: It works but how? Journal of Anxiety disorder. 21, 243-264.ACCF/AHA Guideline for the Management of Heart Failure.http://circ.ahajournals.org/. Zulmi, Asrul. (2018) Hubungan Dukungan Keluarga Terhadap Kualitas Hidup Pasien Gagal Jantung Kongestif Di Instalasi Elang Rsup Dr. Kariadi Semarang. http://repository.unimus.ac.id/1727 